\title{
MANAGING SATISFACTION IN CULTURAL EVENTS. EXPLORING THE ROLE OF CORE AND PERIPHERAL PRODUCT
}

\author{
Manuel Cuadrado-García* \\ Carmen Pérez-Cabañero** \\ Juan D. Montoro-Pons ${ }^{* * *}$
}

Received: 11. 5. 2016

Accepted: 12.5 .2017

Review

UDC 791.6:658.8

This paper measures satisfaction with a cultural event following an innovative approach by differentiating between the art form itself (core product) and the main attributes connected with it (augmented product). 122 individuals (out of 820 visitors) were interviewed on their overall satisfaction and on different aspects of their visiting experience. Multivariate techniques such as ANOVA, principal component factor analysis and regression were performed to analyse the data. Results show the importance of both the core and the peripheral product in measuring satisfaction with a cultural event, thereby highlighting their importance for product management in the arts. The small sample, the specificity of the data and the bias of the distribution have prevented further multivariate analysis. A future area of research is on antecedents to customer satisfaction in the arts field. The contribution of peripheral elements to satisfaction should not be underestimated. Despite artists' freedom to produce the work of art, a series of peripheral elements should be designed along with the other variables of the marketing mix in order to adapt and differentiate the artistic production to the target audience. This paper contributes a different perspective to measuring satisfaction in the arts context while considering the role of the core product and its peripherals.

Keywords: Cultural events, satisfaction, marketing research, multivariate analysis.

* Manuel Cuadrado-García, Associate Professor, University of Valencia, Department of Marketing, Avda. de los Naranjos s/n 46022 Valencia, Spain, E-mail: manuel.cuadrado@uv.es

** Carmen Pérez-Cabañero, Assistant Professor, University of Valencia, Department of Marketing, Avda. de los Naranjos s/nº, 46022 Valencia, Spain, E-mail: perezcar@uv.es

*** Juan D. Montoro-Pons, Associate Professor, University of Valencia, Department of Marketing, Avda. de los Naranjos s/nº 46022 Valencia, Spain, E-mail: Juan.D.Montoro@uv.es 
Management, Vol. 22, 2017, 1, pp. 157-174

M. Cuadrado - García, C. Pérez-Cabañero, J. D. Montoro-Pons: Managing satisfaction in ...

\section{INTRODUCTION}

Satisfaction is a key concept within the marketing discipline and specifically within the area of consumer behaviour. Satisfaction in the arts is mostly derived from a combination of three elements: the subjective and experiential aspects of the cultural product, the quality of the venue and the quality of the associated peripheral services (Hume, 2008a). According to this author, studies on satisfaction with cultural events are key to understanding customer motives to repurchase subscription which can increase the arts organization's profitability, this being a main goal of the currently complex entertainment arena.

This study focuses on satisfaction among visitors of an art exhibition, namely, on a cultural service experience. Research on satisfaction in this context has derived from marketing studies of arts and culture (Baumol and Bowen, 1966; Kotler and Levy, 1969, Levy and Czepiel, 1975; Kirpalani, 1975; Nielsen and McQueen, 1975; Mokwa, Dawson and Prieve, 1980; Evrard and Colbert, 2000). In this context, Colbert (1993) underlines the independence of the cultural product from the remaining variables of the marketing mix. In other words, the cultural product arises independently of the market needs and preferences. Once the work of art is created, marketing managers would look for the audience interested in such a product and then form the suitable price and make promotion and distribution decisions. Revisiting this model, Cuadrado and Molla (2000b) include the difference between core and peripheral product following Laczniak's (1980) proposal. The core product - a work of art, refers to a creation independent of consumers and aimed at preserving an author's artistic integrity. However, the augmented product must be defined together with the other variables of the marketing mix to make the cultural offer more attractive, competitive and adapted to the audience. The final aim is to have more satisfied audiences while allowing artists and arts organizations to reach their objectives.

Within studies on satisfaction, the role of the formal and augmented product in the assesment of satisfaction with a cultural service has received scant attention. This study considers the importance of both the formal product, the artistic performance or activity itself, and the augmented product, i.e. the attributes connected with the artistic event, including amenities such as cloakroom facilities, parking facilities, etc. (Hume et al, 2006), which support the show (Moses, 2001), in the measurement of satisfaction for future managerial purposes. In other words, we measure the core and the peripheral product related to the consumer's satisfaction experience in the cultural service 
Management, Vol. 22, 2017, 1, pp. 157-174

M. Cuadrado - García, C. Pérez-Cabañero, J. D. Montoro-Pons: Managing satisfaction in ...

arena. In this regard, the work by Joy and Sherry (2003) examining different determinants of art appreciation in a museum through qualitative research supports our research. Moreover, previous research in this context has found that the core and peripheral services have different impacts on service management effectiveness (Ferguson et al., 1999). Customers make their repurchase decisions based on the perceived quality of both core and peripheral services, mediated by perceived value and customer satisfaction (Hume, 2008 b). Further research has shown that only the quality of peripheral services has a direct impact on customer's intention to return (Hume and Sullivan, 2010).

The present work includes a review of the relevant literature on satisfaction essential for the rigour of the empirical research. After a presentation of the study event, there is a description of the quantitative research carried out through personal survey and aimed at analysing visitors' assessments of the exhibition itself and the exhibition peripherals. Finally, the paper closes with a discussion on research findings and its implications.

\section{MEASURING SATISFACTION IN ARTS AND CULTURE}

Customer satisfaction is mostly defined by means of comparing a product's perceived performance in relation to pre-consumption expectations. Customers experience various levels of satisfaction or dissatisfaction after each service experience according to the extent to which their expectations were met or exceeded. This comparative process is related to affect and cognitive elements, with the increasing attention to the former. Oliver (1999) relates satisfaction to the product's pleasurable level of consumption-related fulfilment, whereas Kotler and Keller (2006) allude to a person's feelings of pleasure or disappointment.

In literature, the majority of the models developed for explaining the origin of satisfaction are variations on Oliver's (1980) traditional disconfirmation of expectations model. However, later works offer new perspectives in this field. Firstly, some complementary processes such as complaining patterns, attribution of causality and the consumer's affective feelings are studied for their influence on satisfaction (Bearden and Teel, 1983; Oliver and DeSarbo, 1988; Oliver, 1993). Thus, satisfaction judgments do not come solely from the comparison between product expectations and performance. A second line of research shows that product performance is not only compared with the expectations, but also with other elements depending on the situation of purchase or consumption (Cadotte, Woodruff and Jenkins, 1987), consumer desires (Spreng and Olshavsky, 1993; Spreng, MacKenzie and Olshavsky, 
1996) or ideal performance (Tse and Wilton, 1988). Finally, some works are focused on determining the conditions which modify the influence of the variables that take part in the disconfirmation of expectations process, that is to say, performance, expectations and disconfirmation. For example, Churchill and Suprenant (1982) study the effects of the durability of goods whereas Yi (1993) focuses on the different degrees of product ambiguity. Johnson, Anderson and Fornell (1995) state that satisfaction with previous purchases determines the relationships among the disconfirmation variables. Therefore, the primary disconfirmation model remains, albeit with greater complexity. As further processes complement the original comparison, further variables are taken into consideration and their influence may vary depending on the purchase or consumption situation.

Satisfaction measurement in cultural events is not unique and every researcher adapts the concept to the particular context under consideration. There are two main veins of research depending on the considered timing for satisfaction measurement: as a global assessment of the experience or as an evolving feeling during the course of an event. The former focuses mainly on single day activities (Hultsman, 1998) and the latter is commonly studied for multi-day leisure events and considers satisfaction as a multi-faceted concept (Hultsman, 1998; Lee, Datillo and Howard, 1994; Vogt and Stewart, 1998). Similarly, Madrigal (2003) tests a model of sporting event consumption where spectators' judgments are influenced by their emotions and affective expectations during the course of a basketball game. The current research is included among those that ask customers for a single overall assessment of satisfaction after attending the event.

Most papers dealing with cultural events focused on satisfaction as a postconsumption phenomenon and omit the role of expectations in its measurement (Minor, Wagner, Brewerton and Hausman, 2004; Martínez Caro and Martinez García, 2007; Lee, Yang and Lo, 2008; Tse and Weber, 2008; Hume and Sullivan, 2010). In this regard, several authors state that expectations play a minor role in services (Jayanti and Jackson, 1991). Moreover, visitors' expectations may be imprecise and vague in certain cultural events (Bourdeau, De Coster and Paradis, 2001). When leisure activities take place once, that is, when they are not periodically reoccurring, they are perceived as especially intangible and uncertainty related to performance is high. Visitors with little or null experience of such events will not have clear expectations about them so satisfaction is developed after the visitor's experience with the event. Therefore, satisfaction with such leisure and cultural events is clearly a post-consumption phenomenon. 
Management, Vol. 22, 2017, 1, pp. 157-174

M. Cuadrado - García, C. Pérez-Cabañero, J. D. Montoro-Pons: Managing satisfaction in ...

Grounding the research on the studied literature ands considering both formal and augmented attributes of the product, as well as the specific traits of the object of study, we defined a six-item Likert scale for measuring satisfaction with an exhibition omitting the role of expectations. They included the work of art, the spatial layout, the setting, the information provided, the advertising material and the features of the environment of the cultural event.

\section{EMPIRICAL RESEARCH: STUDY OBJECT, OBJECTIVES AND METHODOLOGY}

The object of study was an exhibition of black-and-white pinhole photographs that was held in two intermodal freight containers located in a university campus. Their informal aesthetics were in keeping with the alternative photographic process used in the exhibition (pictures were taken with tins). The two containers were placed 100 meters apart and highlighted with white vinyl strips on the outside. One of them displayed the words "This is an exhibition..." on both sides and the other container was marked with the words "This is a camera...".

The first container housed the photography exhibition, which contained a selection of 25 photographs of an international pop-rock music festival, very popular among university students. This was in line with previous research which has shown that immersion in an aesthetic experience is tied to the presence of clear referents within the experiential context (Caru and Cova, 2011). Thus, each photograph was exhibited together with its corresponding negative and pictures showing how it had been taken. With the aim of enhancing an understanding of the art of taking and producing photographs, volunteer students from a postgraduate course in cultural management were present on site, trained to explain the technique to all the visitors. The second container, with a didactic content and used to promote the exhibition, was fitted out as a gigantic pinhole camera. Small groups of visitors to the exhibition, mostly university students, were able to go inside the hermetically sealed container and experience the phenomenon of the way the light forms images and the way a photograph is taken.

The exhibition, lasting ten days, was visited by 820 visitors. There was evidence of a favourable reception, despite the limited opening hours of five hours a day, coinciding with the working day of the target public. In order to find out how sensible it was to hold such an exhibition in an alternative space and to show that the outcome of the cultural activity had been satisfactory, 
Management, Vol. 22, 2017, 1, pp. 157-174

M. Cuadrado - García, C. Pérez-Cabañero, J. D. Montoro-Pons: Managing satisfaction in ...

research was undertaken. It was designed mainly to examine the degree of visitor satisfaction with the different exhibition components.

In other words, the main purpose of the exploratory research was to analyse satisfaction with attendance of a cultural activity such as an exhibition. Specifically, measuring satisfaction in this research aimed at differentiating between the artform itself and the accompanying features connected with it. In other words, between the core and the peripheral product. Thus, our general objective was to assess attendants' satisfaction with the core exhibition and its peripheral elements along with some further aspects such as an awareness, attendance habits, timing aspects, motivation, overall and selective satisfaction and visitor's profile. In this regard, research questions were:

1. How did visitors hear about the exhibition?

2. What was their overarall experience?

3. Why did visitors attend the exhibition?

4. How did visitors assess core and peripheral elements of the exhibition?

5. Were there any satisfaction differences in terms of demographic variables?

The questionnaire designed to collect the information was divided into different sections: habits, motivation, satisfaction with the exhibition and visitors' demographic and academic background. Motivation was measured through a five-point Likert scale referred to the importance of eleven proposed goals of attending the exhibition. This scale was based on previous research by Cuadrado and Mollá (2000a). According to the previously reviewed literature, satisfaction is considered as a post-consumption experience. We anticipated that visitors' expectations of the pinhole photography exhibition would be mostly imprecise so the role of expectations was omitted.

Consequently, satisfaction was measured by focusing on the visitor's perception of the various components of the cultural activity in relation to the core service and additional peripheral elements. Specifically, satisfaction was measured through a six-point Likert scale on the core service (the selection of exhibited pinhole photos) and five other aspects such as the poster, the venue, the layout, the information provided by the guides and the lighting. In building this satisfaction scale we followed Giese and Cote's (2004) recommendations for adapting to the context of interest. They point out that when measuring satisfaction the researcher should relate the graduation of the affective response, the most appropriate timing and the particular activities with influence on the overall satisfaction assessment. Thus, we used a short, balanced and multi-item 
Management, Vol. 22, 2017, 1, pp. 157-174

M. Cuadrado - García, C. Pérez-Cabañero, J. D. Montoro-Pons: Managing satisfaction in ...

scale whose Cronbach's alpha is 0.67 . As supported by literature, this value is accepted in exploratory research.

Fieldwork in the form of face-to-face interviews was carried out in 2010 while information analysis was conducted through subsequent years. Subjects were chosen using systematic random sampling, approximately every sixth visitor as they were leaving the exhibition. Overall 140 visitors out of around 820 visitors were approached during the research period and 122 agreed to be interviewed. Participants were informed that their opinion would be completely anonymous. Data analysis included SPSS 17.0 computer software.

Of the total visitors interviewed, $61.5 \%$ were women and $38.5 \%$ were men. Of these, $79.2 \%$ were students, $9.2 \%$ teachers and 5.8\% administrative staff. These percentages agreed with the population proportions. Average age was 26.24 years. Of the students who came to the exhibition, $25.3 \%$ were studying Economics, $17.9 \%$ Business, 13.7\% Law and 13.7\% Social studies.

\section{RESULTS}

\subsection{Awareness, habits and motivation}

For the purpose of analysing research questions 1 to 3 a descriptive analysis was undertaken. Although these findings were already published as a case study in a university textbook (Cuadrado, 2010) we briefly summarized them in order to contextualize further analysis. When asked how they found out about the exhibition, $41 \%$ of visitors said that they saw it while walking pass the exhibition area and $38.5 \%$ learned about the exhibition from an e-mail sent by the University. These two sources of information were the most important ones for exhibition awareness. In addition, $12.3 \%$ of visitors knew about the exhibition because a friend had told them about it. However, the exhibition poster, designed by the artists and conveniently located on different billboards at the campus, had little impact. Only $1.6 \%$ of the respondents pointed out this alternative. This result was surprising but highly important as posters have been notably used to promote not only exhibitions but other cultural activities.

Regarding attendance aspects, only $40 \%$ of visitors attended the exhibition alone whereas $60 \%$ came with somebody else. From these, $23.9 \%$ went with a friend, $52.1 \%$ with two friends and $23.9 \%$ with three or more people. In line with several authors, social goals of attendance have always been important for customers in attending any cultural event. Furthermore, Morgan (2006) states that enjoying the company of friends is the real reason for attending an event. 
Management, Vol. 22, 2017, 1, pp. 157-174

M. Cuadrado - García, C. Pérez-Cabañero, J. D. Montoro-Pons: Managing satisfaction in ...

With respect to the timing, the finding that $69.4 \%$ of visitors attended the exhibition in the morning and $30.6 \%$ in the afternoon are again in line with population proportions. Half the visitors spent between five and ten minutes looking at the pinhole photos. The limited number of pictures, the small exhibition setting and the little time campus users had between classes could explain the brevity of the visit. However, this result does not have a negative meaning as enjoyment is not time-dependent.

Results also show that curiosity about the exhibition (4.40 out of 5), as it seemed unusual and interesting (4.26), attractiveness of the exhibition and interest (4.29) were the most important motives for attending. Having some free time (3.93), loving photography (3.93) and the desire to have a good time (3.66) and learn something (3.58) were also highly assessed. Therefore, the exhibition fulfils the statement that leisure activities should be designed to refresh, stimulate and entertain and to provide pleasurable emotional experiences for people in their free time (Hull, 1990).

\subsection{Satisfaction}

Overall assessment of the exhibition was high with an average score of 7.89 out of 10 (Table 1). Generally, all visitors enjoyed it as the minimum score was 5 out of 10 and the maximum was 10 . Regarding the satisfaction features, also included in Table 1, all of them were favourably assessed as their scores are above four on a six-point Likert scale.

Table 1. Satisfaction assessment

\begin{tabular}{|l|c|c|c|}
\hline & Average & $\begin{array}{c}\text { Standard } \\
\text { deviation }\end{array}$ & Min/ Max \\
\hline The photos are interesting & 5.09 & 0.953 & $3 / 6$ \\
The exhibition poster is attractive & 4.08 & 1.406 & $1 / 6$ \\
The exhibition setting is adequate & 4.69 & 1.267 & $1 / 6$ \\
The spatial layout is logical & 5.16 & 0.918 & $3 / 6$ \\
There is sufficient information on the & 4.85 & 1.133 & $1 / 6$ \\
exhibition & & & 1.265 \\
The lighting is adequate & 4.54 & 1.111 & $5 / 10$ \\
\hline Overall assessment of the exhibition & 7.89 & & \\
\hline
\end{tabular}

Source: Research results.

The contribution of the core and peripheral elements to satisfaction is clear as shown by the scores for the corresponding items. Visitors gave the central element of the exhibition, that is the selection of pictures, high scores (5.09). 
Management, Vol. 22, 2017, 1, pp. 157-174

M. Cuadrado - García, C. Pérez-Cabañero, J. D. Montoro-Pons: Managing satisfaction in ...

Other aspects of the exhibition, such as the spatial layout, scored highest (5.16), the exhibition setting scored 4.69 and the lighting 4.54, among other factors. The poster had the minimum score with 4.08 in accordance with the little impact it had among visitors.

ANOVA tests were conducted to find statistical differences between the satisfaction reported and the profile of the visitors interviewed. None of them gave positive results probably due to the limited sample. We do not reproduce them to simplify the analysis. Therefore, satisfaction was quite high among all visitors, independently of their gender, age or academic background.

Principal component factor analysis was done to simplify the data on satisfaction. KMO and Barlett's statistics confirmed the advisability of this technique for the current data. Using maximum likelihood extraction and Varimax rotation, statistical analysis provided a clear result with two dimensions. Only two factors had Eigenvalues exceeding one with $53.10 \%$ total explained variance. Table 2 contains both factors' loadings from the rotated matrix. The two extracted factors are quite interesting as one is related to inner features of the exhibition (spatial layout, information available, selection of pinhole photos and the lighting) and the other one to augmented features (the poster and the exhibition setting). Results must be considered with caution due to the low percentage of explained variance. We describe and label the two factors as follows:

Factor 1 was named Core product, as it was formed with the following variables: "The spatial layout is logical", "There is sufficient information on the exhibition", "The photos are interesting" and "The lighting is adequate".

Factor 2 was labelled Peripheral product, as it comprises the variables "The exhibition poster is attractive" and "The exhibition setting is adequate".

The mean of every factor was then calculated. As shown in Table 2, the factor Core product scored slightly higher than the factor containing peripheral aspects of the cultural event.

Finally, a regression analysis was performed in order to investigate the main determinants of the overall satisfaction with the cultural event. The dependent variable was overall satisfaction and all potential independent variables in the database were included, such as the two factors summarizing satisfaction with the exhibition and other individual characteristics of the survey-takers (i.e. gender, whether the survey taker was 
Management, Vol. 22, 2017, 1, pp. 157-174

M. Cuadrado - García, C. Pérez-Cabañero, J. D. Montoro-Pons: Managing satisfaction in ...

student/faculty/staff/other, degree in case of student...). Those variables which proved non-significant at the standard level (greater than 10\%) were dropped from the regression. Interestingly, only the two factors summarizing satisfaction were significant.

Table 2. Factor loadings on satisfaction

\begin{tabular}{|l|c|c|}
\hline & Factor $\mathbf{1}$ & Factor 2 \\
\hline The exhibition poster is attractive & & 0.847 \\
The exhibition setting is adequate & 0.711 \\
The spatial layout is logical & 0.729 & \\
There is sufficient information on the exhibition & 0.773 & \\
The photos are interesting & 0.518 & \\
The lighting is adequate & 0.648 & \\
\hline Total explained variance & \multicolumn{2}{|c|}{$53.1 \%$} \\
\hline Eigenvalue & 2.107 & 1.079 \\
\hline Mean & 4.90 & 4.38 \\
Standard deviation & 0.74 & 1.07 \\
\hline
\end{tabular}

Source: Research results.

The main results are shown in Table 3. It shows the point estimate for the coefficients, standard errors and significance levels (P-value), and the 95\% confidence interval. It also includes the value of a test for the joint significance of the model ( $\mathrm{F}$ test) and its significance below, and two more measures of the suitability of fit (raw and adjusted coefficient of determination).

The regression results confirm that the overall satisfaction can be explained by two factors: the core and peripheral product of a cultural event. Moreover, both of them are equally important to explain overall satisfaction of a cultural product. Note that the standardized coefficients (not included) are unsurprisingly quite close to the estimated ones: 0.323 for the core product and 0.317 for the peripheral product. Based on these results, we can conclude that the quantitative impact of the core and peripheral product on overall satisfaction was rather similar.

In order to check whether the closeness between both estimates was due to actual parameters being equal, a Wald test on the coefficients equality was performed. The value of the test statistic was 0.01 , with a minimum significance level equal to 0.9296 , which does not allow to reject the null hypothesis that both estimated coefficients are equal. Consequently, in the design of the cultural product arts managers should give equal weight to peripheral and core aspects 
Management, Vol. 22, 2017, 1, pp. 157-174

M. Cuadrado - García, C. Pérez-Cabañero, J. D. Montoro-Pons: Managing satisfaction in ...

as the former may increase overall satisfaction with the cultural product. Examples of such would be the poster or other promotional information, and the venue of the cultural event.

Table 3. Regression analysis

\begin{tabular}{|c|c|c|c|c|c|c|}
\hline & Coef. & SE & t & P-val & \multicolumn{2}{|c|}{$\begin{array}{l}\text { [95\% Confid. } \\
\text { Interval] }\end{array}$} \\
\hline Core product (factor 1) & 0,349 & 0,093 & 3,770 & 0,000 & 0,165 & 0,533 \\
\hline Peripheral product (factor 2) & 0,338 & 0,091 & 3,700 & 0,000 & 0,157 & 0,519 \\
\hline Number of obs & 111 & & & & & \\
\hline $\mathrm{F}(2,108)$ & 14,180 & & & & & \\
\hline Prob $>$ F & 0,000 & & & & & \\
\hline $\mathbf{R 2}$ & 0,208 & & & & & \\
\hline Adj R2 & 0,193 & & & & & \\
\hline Root MSE & 0,981 & & & & & \\
\hline
\end{tabular}

Source: Research results.

\section{DISCUSSION AND MANAGERIAL IMPLICATIONS}

The current research has analysed satisfaction related to a cultural activity, specifically a photo exhibition, distinguishing between core and peripheral components of the service. Visitors' satisfaction was measured, using an adapted scale, as a post-consumption experience without considering the role of expectations. The results from the personal survey among visitors show a high overall satisfaction, with high scores for the central elements of the exhibition (that is, the selection of photohtaphs, the spatial layout, the information provided and the lighting) as well as its peripheral elements (such as the poster and the exhibition setting). This study can help organizers of cultural events to gain better understanding of the customer satisfaction process.

Furthermore, arts managers should pay attention not only to the core service for the formal product but also for the augmented product as both of them contribute to post-consumption satisfaction. The contribution of peripheral elements to satisfaction should not be underestimated (Hume and Sullivan, 2010) and even expectations about them can play a role (Whipple and Thach, 1988). According to Cuadrado and Molla (2000b) the peripheral elements integrated in the augmented product of the cultural event should be designed along with the other variables of the marketing mix to adapt the cultural event 
Management, Vol. 22, 2017, 1, pp. 157-174

M. Cuadrado - García, C. Pérez-Cabañero, J. D. Montoro-Pons: Managing satisfaction in ...

to the target of the cultural entity. Despite the freedom of the artist to define the formal product (that is, the cultural event itself), in other words, the product orientation, a market orientation should be designed by enhancing the impact of peripheral elements which can be very useful to differentiate the cultural event and to increase overall satisfaction with the cultural product. These results confirm the importance of considering both product orientation and market orientation when applying marketing principles and decisions in the arts context. The challenge to leisure/cultural or non leisure/cultural organizations offering this type of activities is to include all these elements in their offerings to make the event a memorable experience (Morgan, 2006) as consumers are not only seeking a core show but an entire experience (Hume, 2008a).

As Martínez Caro and Martínez García (2007) point out, "customer satisfaction is driven by cognitive and affective factors where the level of excitement exerts a stronger influence on satisfaction". Core and peripheral quality of service also contribute to appraisal emotion, which is an antecedent of satisfaction and repurchase intention (Hume and Sullivan, 2010). This means that cultural events managers should not only make an effort to offer a high quality cultural event, they should also consider all the additional elements which can stimulate visitors' emotions during the experience.

Cultural managers should include apropriate referents to facilitate immersion in the aesthetic event. These referents must be understandable to the target audience by virtue of their cultural background although pedagogical elements, additional information and assistance can also help the user (Caru and Cova, 2005). The second container transformed into a big camera obscura allowed visitors to co-produce the aesthetic event and experience the light effects, stimulating their emotions and feelings. According to Caru and Cova (2005) "if an artistic experience is to be successful, the provider of that experience will have to support the consumer - or treat the consumer as a coproducer- throughout the immersion process" so the second container played a key role in the success of the exhibition.

Our findings also involve other implications for management and marketing in line with the work by Hume et al (2006). Regarding promotion decisions, electronic mails and strategic location of the setting should be emphasized for exhibition awareness as they proved to be good promotional tools. The exhibition setting itself, located in the middle of the university campus, contributed a distinctive and memorable appeal to the entire event. On the other hand, printed material like exhibition posters should be carefully designed and distributed. The low impact of the poster on general awareness of 
Management, Vol. 22, 2017, 1, pp. 157-174

M. Cuadrado - García, C. Pérez-Cabañero, J. D. Montoro-Pons: Managing satisfaction in ...

the exhibition may be due to the fact that it was not understood by the target audience which, according to Caru and Cova (2011), means that the referents it contained were not appropriate nor understood. Finally, new cultural events should be adatpted to potential visitiors timing; in this specific case they should be as short as possible short because campus passers by do not have much time to spare.

Many studies on satisfaction usually consider the assessment of different consequent behaviours such as intention to recommend the event or form a repurchase intention. The latter is the purpose of the study in performing arts by Hume, Sullivan and Winzar (2007) which states that "satisfaction was derived from a measurement of the technical qualities of the show; the overall show experience proved to be strongly related to emotion, and/or the functional quality of service delivery, venue quality and the level of satisfaction with the 'performance' of the desired factors". Despite the appeal of such factors we could not assess them. Firstly, because the survey was conducted shortly after attendance so we could not find out about subsequent word of mouth. Secondly, the exhibition was unique (that is, it is not periodically reoccurring) so patronage is unlikely to take place. As Harrison and Shaw (2004) state, in certain events only very satisfied visitors repeat the experience shortly afterwards. This is because consumers may not see a need to return unless the product changes substantially. All in all, the high satisfaction level reported in this survey has encouraged university arts managers to organize similar events as a complement to the regular academic activities.

Among the limitations of this study, the small sample, the bias of the distribution, mainly because of the age, level of studies and background of the visitors, have prevented further multivariate analysis. It would have been interesting, for example, to obtain clusters of visitors as segmentation always involves making ad-hoc marketing decisions to satisfy customer needs. In addition to that, following Morgan (2006), we could have also included other items in the satisfaction scale related to emotions as they are closely related to satisfaction.

Finally, it is also worth to note that the specificity of the data, as they cover only a specific type of art, prevents us to generalize results in the arts sector. A vast area of research is investigating antecedents to customer satisfaction in the cultural field. Future research could also include measurement of further postconsumption behaviours such as those commented above: intention to return and intention to recommend it to peers. 


\section{REFERENCES}

1. Bauer, T., Law, R., Tse, T., Weber, K. (2008). Motivation and satisfaction of mega-business event attendees, International Journal of Contemporary Hospitality Management, 20 (2), pp. 228-234.

2. Baumol, W.J. and Bowen, W.G. (1966). Performing Arts. The Economic Dilemma, Twentieth Century Fund, Cambridge.

3. Bearden, W.O and Teel, J.E. (1983). Selected determinants of consumer satisfaction and complaint reports, Journal of Marketing Research, 20 (February), pp. 21-28.

4. Bourdeau, L., De Coster, L., Paradis, S. (2001). Measuring satisfaction among festivalgoers, International Journal of Arts Management, 3 (2), pp. 40-50.

5. Cadotte, E. R, Woodruff, R. B., Jenkins, R. G. (1987). Expectations and norms in models of consumer satisfaction, Journal of Marketing Research, 24 (August), pp. 305-314.

6. Caru, A., Cova, B. (2005). The impact of service elements on the artistic experience: The case of classical music concerts, International Journal of Arts Management, 7 (2), pp. 39-54.

7. Caru, A., Cova, B. (2011). Can the generation gap impede immersion in an exhibition? The case of Annisettanta, International Journal of Arts Management, 13 (2), pp. 16-28.

8. Churchill, G. A., Suprenant, C. (1982). An investigation into the determinants of consumer satisfaction, Journal of Marketing Research, 19 (November), pp. 491-504.

9. Colbert, F. (1993). Le marketing des arts et de la culture, Gaëtan Morin Editeur, Québec.

10. Cuadrado, M. (ed.) (2010). Mercados culturales. Doce estudios de marketing, UOC editorial Barcelona.

11. Cuadrado, M., Mollá, A. (2000a). Grouping performing arts consumers according to attendance goals, International Journal of Arts Management, 2 (3), pp. 54-60.

12. Cuadrado, M., Mollá, A. (2000b). La relación consumidor-artes: Un equilibrio entre satisfacción de necesidades y libertad creativa, Estudios sobre Consumo, 53, pp. 23-32.

13. Evrard, Y., Colbert, F. (2000). Arts marketing: A new discipline entering the millennium?, International Journal of Arts Management, 2 (2), pp. 413.

14. Ferguson, R. J., Paulin, M., Pigesassou, C., Gauducho, R. (1999), Assessing service management effectiveness in a health resort: 
Management, Vol. 22, 2017, 1, pp. 157-174

M. Cuadrado - García, C. Pérez-Cabañero, J. D. Montoro-Pons: Managing satisfaction in ...

Implications of technical and functional quality, Managing Service Quality, 8 (1), pp. 58-65.

15. Giese, J. L., Cote, J. A. (2000). Defining consumer satisfaction, Academy of Marketing Science Review, 1 (1), pp. 1-24.

16. Harrison, P., Shaw, R. (2004). Consumer satisfaction and post-purchase intentions: An exploratory study of museum visitors, International Journal of Arts Management, 6 (2), pp. 23-32.

17. Hull, R.B. (1990). Emotion and leisure: Causes and consequences, Journal of Leisure Research, 22, pp. 55-67.

18. Hultsman, W. (1998), The multi-day, competitive leisure event: Examining satisfaction over time, Journal of Leisure Research, Vol. 30 No. 4, pp. 472-497.

19. Hume, M., Sullivan Mort, G., Liesch, P., Winzar, H. (2006), Understanding service experience in non-profit performing arts: Implications for operations and service management, Journal of Knowledge Management: Special Issue, Non-for-profit Government and Voluntary Sector Management, 24 (4), pp. 304-346.

20. Hume, M., Sullivan Mort, G., Winzar, H. (2007). Exploring Repurchase Intention in a Performing Arts Context: Who comes? And why do they come back?, International Journal of Not-Profit and Voluntary Sector Marketing, 12 (2), pp. 135-148.

21. Hume, M. (2008a). Developing a conceptual model for repurchase intention in the performing arts: The roles of emotion, core service and service delivery, International Journal of Arts Management, 10 (2), pp. 4055.

22. Hume, M. (2008b). Understanding core and peripheral service quality in customer repurchase of the performing arts, Managing Service Quality, 18 (4), pp. 349-369.

23. Hume, M., Sullivan Mort, G. (2010). The consequence of appraisal emotion, service qulaity, perceived value and customer satisfaction on repurchase intent in the performing arts, Journal of Services Marketing, 24 (2), pp. 170-182.

24. Jayanti, R., Jackson, A. (1991). Service satisfaction: An exploratory investigation of three models, Advances in Consumer Research, 18, R.H. Holman and M.R. Solomon eds. Ann Arbor, MI: Association for Consumer Research, pp. 603-610.

25. Johnson, M. D., Anderson, E. W., Fornell, C. (1995). Rational and adaptative performance expectations in a customer satisfaction framework, Journal of Consumer Research, 21 (March), pp. 695-707. 
26. Joy, A., Sherry, J. F. (2003). Speaking of art as an embodied imagination: A multisensory approach to understanding aesthetic experience, Journal of Consumer Research, 30, pp. 259-282.

27. Kirpalani, V. H. (1975). Marketing and the arts: Discussion, in R. C. Curhan (ed.) New marketing for social and economic progress and marketing's contributions to the society. American Marketing Association, pp. 396-398.

28. Kotler, P., Keller, K. L. (2006), Marketing Management, 12ed. Pearson Prentice Hall.

29. Kotler, P., Levy, S. J. (1969). Broadening the concept of marketing, Journal of Marketing, 33, pp. 10-15.

30. Laczniak, G. R. (1980). Product management and the performing arts, in Mokwa, M. P, Dawson, W. M., Prieve, E. A. (eds.), Marketing the Arts, Praeger, New York, pp. 124-138.

31. Lee, C., Yang, S., Lo, H. Y. (2008). Customer satisfaction and customer characteristic in festival activity. A case of 2006 Kenting Wind Chime Festival, International Journal of Culture, Tourism and Hospitality Research, 2 (3), pp. 234-249.

32. Lee, Y., Dattilo, J., Howard, D. (1994). The complex and dynamic nature of leisure experience, Journal of Leisure Research, 26, pp. 195-211.

33. Levy, S. J., Czepiel, J. A. (1975), Marketing and aesthetics, in R.C. Curhan (ed.) New marketing for social and economic progress and marketing's contributions to the society, American Marketing Association, pp. 386-391.

34. Madrigal, R. (2003). Investigating an evolving leisure experience: Antecedents and consequences of spectator affect during a live sporting event, Journal of Leisure Research, Vol. 35 No. 1, pp. 23-48.

35. Martínez Caro, L., Martínez García, J. A. (2007). Consumer satisfaction with a periodic reoccurring sport event and the moderating effect of motivations, Sport Marketing Quarterly, 16, pp. 70-81.

36. Minor, M.S., Wagner, T., Brewerton F. J., Hausman, A. (2004). Rock on! An elementary model of customer satisfaction with musical performances, Journal of Services Marketing, 18 (1), pp. 7-18.

37. Mokwa, M. P., Dawson, W. M., Prieve, E. A. (1980). Marketing the arts. Praeger ed. New York.

38. Morgan, M. (2006). Making space for experiences, Journal of Retail \& Leisure Property, 5 (4), pp. 305-313.

39. Moses, S. (2001). Have a plan and make the most of arts and culture, Public Management, 83 (1=, pp. 18-21.

40. Nielsen, R. P., McQueen, C. (1975). Performing arts consumer behaviour: An exploratory study, in R.C. Curhan (ed.) New marketing for social and 
Management, Vol. 22, 2017, 1, pp. 157-174

M. Cuadrado - García, C. Pérez-Cabañero, J. D. Montoro-Pons: Managing satisfaction in ...

economic progress and marketing's contributions to the society, American Marketing Association, pp. 392-395.

41. Oliver, R. L. (1980). A cognitive model of the antecedents and consequences of satisfaction decisions, Journal of Marketing Research, 17 (November), pp. 460-469.

42. Oliver, R. L. (1993). Cognitive, affective and attribute bases of the satisfaction response, Journal of Consumer Research, 20 (December), pp. 418-430.

43. Oliver, R. L. (1999). Whence consumer loyalty?, Journal of Marketing, 63, pp. 33-44.

44. Oliver, R. L., DeSarbo, W. S. (1988). Response determinants in satisfaction judgements, Journal of Consumer Research, 14 (March), pp. 495-507.

45. Spreng, R. A., Olshavsky, R.W. (1993). A desires congruency model of consumer satisfaction, Journal of the Academy of Marketing Science, 21 No. 3, pp. 169-177.

46. Spreng, R. A. McKenzie, S. B., Olshavsky, R. W. (1996). A reexamination of the determinants of consumer research, Journal of Marketing, 60 (July), pp. 15-32.

47. Tse, D. K., Wilton, P. C. (1988). Models of consumer satisfaction formation: An extension, Journal of Marketing Research, 25 (May), pp. 204-212.

48. Vogt, C. A. and Stewart, S. I. (1998). Affective and cognitive effects of information use over the course of a vacation, Journal of Leisure Research, 30, pp. 498-520.

49. Whipple, T. W., Thach, S. V. (1988). Group tour management: Does good service produce satisfied customers?, Journal of Travel Research, 22, pp. 16-21.

50. Yi, Y. (1993). The determinants of consumer satisfaction: The moderating role of ambiguity, Advances in Consumer Research, 20, pp. 502-506.

\section{UPRAVLJANJE ZADOVOLJSTVOM POSEBNIM DOGAĐANJIMA U KULTURI: ISTRAŽIVANJE ULOGE KLJUČNOG I PERIFERNOG PROIZVODA}

\section{Sažetak}

U ovom se radu mjeri zadovoljstvo s posebnim događanjem u kulturi, koristeći inovativni pristup diferenciranju između umjetničkog događaja (kao ključnog proizvoda) i ključnih atributa, povezanih $\mathrm{s}$ događajem (prošireni proizvod). Intervjuirano je 122 (od ukupno 820) posjetitelja, pri čemu su analizirani njihovo 
Management, Vol. 22, 2017, 1, pp. 157-174

M. Cuadrado - García, C. Pérez-Cabañero, J. D. Montoro-Pons: Managing satisfaction in ...

ukupno zadovoljstvo i drugi aspekti njihovog ukupnog doživljaja. Podaci se analiziraju korištenjem multivarijantnih statističkih metoda (analizom varijance, faktorskom analizom i regresijom). Dobiveni rezultati pokazuju značaj - kako ključnog, tako i perifernog proizvoda u mjerenju zadovoljstva posebnim događanjem u kulturi, naglašavajući njegov značaj za upravljanje proizvodom u djelatnostima kulture. Daljnja multivarijantna analiza nije bila moguća, zbog malog uzorka, specifičnosti podataka i pristranosti distribucije. Budući istraživački zadaci uključuju analizu prethodnika zadovoljstva kupaca u djelatnostima kulture, pri čemu se ne smije podcijeniti doprinos perifernih elemenata ukupnog proizvoda. Usprkos slobodi umjetnika da kreiraju umjetničko djelo, periferne elemente treba oblikovati sukladno ostalim varijablama marketinškog miksa, kako bi se umjetnički proizvod prilagodio i diferencirao prema ciljnoj skupini. Doprinos ovog rada odnosi se na različitost perspektive mjerenja zadovoljstva kupaca u kontekstu djelatnosti kulture, prilikom analize ključnog i perifernog proizvoda.

Ključne riječi: posebna događanja u kulturi, zadovoljstvo, marketinško istraživanje, multivarijantna analiza 